\title{
BRANDING STRATEGIES FOR SMALL CITIES IN THE INTERNET SPACE
}

\author{
Olga I. Popova \\ Volgograd State University, Volgograd, Russia \\ Svetlana A. Korolkova \\ Volgograd State University, Volgograd, Russia \\ Ekaterina V. Stepanova \\ Volgograd Institute of Management, Branch of Russian Presidential Academy \\ of National Economy and Public Administration, Volgograd, Russia
}

\begin{abstract}
The paper examines the use of communicative strategies and tools for promoting local territories on the Internet on the material of tourist sites, social networks and blogs. Internet strategy depends on the promoted territory, pragmatic goals and determines the selection of tools and language means. The authors applied an integrative communicative approach. It was established that a European small town brand is developed by employing macro strategy including historical, cultural, environmental, and gastronomic references represented in several foreign languages. The small Russian town branding is implemented through micro-strategies with a heterogeneous brand structure, sometimes, related to some important events, not supported by significant historical facts in Russian. Lingua-pragmatic analysis of data has shown that specialized travel sites of European and Russian small towns use mostly informative tactics for promoting their territories while communicative tactics of social networks and blogs are of a greater emotion and evaluative value. The experience of European small towns, and communicative strategies of brand promotion in particular, might be relevant for Russian locality identification and differentiation, small town brand development, formation of cultural apprehension and loyalty among the citizens as well as domestic and foreign tourists.

Key words: communicative strategy, communicative tactic, branding strategy, small town promotion, linguistic and pragmatic potential.

Citation. Popova O.I., Korolkova S.A., Stepanova E.V. Branding Strategies for Small Cities in the Internet Space. Vestnik Volgogradskogo gosudarstvennogo universiteta. Seriya 2. Yazykoznanie [Science Journal of Volgograd State University. Linguistics], 2020, vol. 19, no. 2, pp. 123-138. (in Russian). DOI: https://doi.org/ 10.15688/jvolsu2.2020.2.11

\section{СТРАТЕГИИ БРЕНДИРОВАНИЯ МАЛЫХ ГОРОДОВ В ИНТЕРНЕТ-ПРОСТРАНСТВЕ}

\section{Ольга Ильинична Попова}

Волгоградский государственный университет, г. Волгоград, Россия

\section{Светлана Азадовна Королькова}

Волгоградский государственный университет, г. Волгоград, Россия

\section{Екатерина Владимировна Степанова}

Волгоградский институт управления - филиал Российской академии народного хозяйства и государственной службы при Президенте РФ, г. Волгоград, Россия 


\section{МАТЕРИАЛЫ И СООБЩЕНИЯ}

Аннотация. Статья посвящена изучению реализации коммуникативной стратегии брендирования как инструмента продвижения территорий в Интернете. Материалом для исследования выбраны туристические сайты, социальные сети и блоги. Для определения содержательных особенностей стратегии в рамках интернет-пространства в зависимости от территории распространения, прагматических установок, языковых средств использован интегративный коммуникативный подход. Установлено, что для продвижения европейских малых городов применяется макро-стратегия как элемент единой государственной стратегии, основанная на исторических, культурных, экологических, гастрономических фактах и реализуемая на нескольких иностранных языках. Отмечено, что брендирование малых городов России осуществляется посредством микро-стратегии с разрозненной структурой брендов, иногда имеющей спонтанный, событийный характер, не подкрепленной значительными историческими фактами на русском языке. С опорой на результаты лингвопрагматического анализа материала показано, что разработчики специализированных туристических сайтов как европейских, так и российских малых городов применяют преимущественно информативные тактики продвижения территорий. Выявлено, что для коммуникативных тактик в социальных сетях и блогах характерны большая эмоциональность и оценочность. О.И. Поповой проанализирован массив данных и на примере г. Брюгге описана стратегия брендирования малых городов на европейских туристических сайтах; С.А. Корольковой на примере г. Камышина рассмотрена стратегия брендирования малых городов на российских туристических сайтах; Е.В. Степановой на примере г. Брюгге и г. Камышина охарактеризована стратегия брендирования малых городов в блогах и социальных сетях.

Ключевые слова: коммуникативная стратегия, коммуникативная тактика, стратегия брендирования, продвижение малых городов, лингвопрагматический потенциал.

Цитирование. Попова О. И., Королькова С. А., Степанова Е. В. Стратегии брендирования малых городов в интернет-пространстве // Вестник Волгоградского государственного университета. Серия 2, Языкознание. 2020. - T. 19, № 2. - C. 123-138. - DOI: https://doi.org/10.15688/jvolsu2.2020.2.11

\section{Введение}

Привлекательный туристический бренд государства и его отдельных территорий становится двигателем создания национального бренда страны. Задачи продвижения бренда территорий включают формирование узнаваемой и недвусмысленной системы идентификации, основанной на фирменном стиле, а также цельного, позитивного набора культурных и имиджевых ассоциаций, связанных с регионом. Брендинг территорий осуществляется ведомствами, организациями и различными маркетинговыми компаниями.

Туристическая привлекательность, по мнению исследователей, определяется туристическим потенциалом территории, при эксплуатации которого обеспечивается оптимальная туристско-рекреационная нагрузка, сохранение туристических ресурсов и возможность получения социально-экономического эффекта без нарушения экологического равновесия окружающей среды (см., например: [Buletova, Zlochevsky, Stepanova, 2017]).

За брендинг территорий в странах Европы несут ответственность несколько ведомств и организаций, реализующих единую стратегию продвижения крупных и малых террито- рий. Например, бренд бельгийского города Брюгге был разработан и внедрен Туристической организацией Бельгии, поддержан и распространяется Национальным туристическим управлением Бельгии [Richards, Duif, 2018]. В России лишь недавно было принято несколько ненормативных актов, регулирующих деятельность в этой сфере. В частности, в сентябре 2019 г. Правительством утверждена Стратегия развития туризма в РФ на период до 2035 года.

В современном мире эффективным каналом реализации стратегии развития туризма стал Интернет. Наиболее влиятельными на мировом рынке брендами, продвижение которых во многом основывается на цифровых технологиях, являются государства (см. об этом: [Anholt, 2009, p. 10]). Интернет активно используется для национальных и муниципальных кампаний по продвижению территорий крупных и малых городов в Европе и России. В условиях информационного общества он стал ключевым каналом трансляции территориального бренда, формирующим образ и ассоциации из набора символов, пресуппозиций, знаний, которые связаны с территорией как в поисковой выдаче, так и глобальном и локальном сетевом контентах. 
Стратегии продвижения территорий в Интернете реализуются посредством разнообразных тактик, в том числе лингвопрагматических (см. например: [Шафранская, 2012; Braun]). Тексты туристического дискурса представлены множеством различных форм: от специализированных интернет-страниц туристических достопримечательностей до сайтов городов и территорий, комментариев к фотографиям и иллюстрациям, блогами в социальных сетях, контентным содержанием видеоблогов и т. д. Вербальная составляющая стратегии, также как и невербальная, направлена на создание позитивного, привлекательного образа территории в коллективном сознании.

Особый интерес для исследования представляет сравнительный анализ брендов малых городов Европы и России. Понимание того, что бренд страны формируется брендами не только столицы, мегаполисов и крупных городов, но и малых городов, многие из которых имеют богатое историческое прошлое и интересное архитектурное наследие, в Европе существует давно. Опыт европейских малых городов, а именно - применяемые коммуникативные стратегии брендирования, разработка комплекса средств по идентификации и дифференциации территории, может быть полезен и в России для создания бренда малых локаций, формирования культурных идентификаций и лояльности в сознании жителей малых городов, внутренних и международных туристов.

Цель статьи заключается в выявлении и сопоставлении стратегий брендирования малых российских и европейских городов в интернет-пространстве, определение прагматических установок, используемых языковых средств на основе интегративного коммуникативного подхода.

\section{Материалы и методы}

Объект нашего исследования - коммуникативные стратегии и тактики как инструменты реализации стратегии брендирования малых городов в интернет-пространстве, направленные на создание позитивного, привлекательного образа территории в коллективном сознании.
Малые города являются духовной и культурной опорой самоидентичности любой страны, имеют значительный туристический потенциал. Однако российским малым и средним городам не просто получить статус привлекательного туристического направления в связи с более слабыми социальными, экономическими и культурными позициями в сравнении с российскими мегаполисами и европейскими городами. Статистически малыми считаются города с населением до 50 тыс. человек, средними - от 50 до 100 тыс., крупными - от 100 до 500 тысяч. Однако большинство российских городов, которые формально являются средними или крупными, фактически (по социо-экономическим и культурным показателям) воспринимаются как малые города. Они не в состоянии предложить потребителю ни интересные архитектурные достопримечательности, ни своеобразные культурные мероприятия, ни благоустроенную городскую среду (качественные дороги, доступный скоростной Интернет, гостиницы и досуг).

Российское интернет-пространство включает разнообразные площадки, где представляется брендируемая территория, например международные туристические платформы (Trip Advisor и др.), национальные туристические платформы (Russia Open, Turprom.ru и др.), локальные, выходящие на национальный уровень (Veter.ru и др.), сайты фестивалей или иных туристически привлекательных событий (Arbuzfest.ru и др.), собственные сайты территорий (http://kamyshinstar.ru/?p=171 и др.), а также социальные сети и блоги (https://vk.com/ arbuzfest_kam, http://www.myjulia.ru/post/431794).

Нами проанализировано 8 российских и 5 европейских сайтов, направленных на продвижение малых городов, а также 70 постов блогов и видеоблогов (42 европейских и 28 российских) на таких площадках, как YouTubers, Twitter, Instagram, VK и др., отобранных на основе тематического указателя малого города, достопримечательностей и важных городских мероприятий, которые являются привлекательными для потенциальных туристов и способствуют созданию бренда малого города.

В исследовании применялся интегративный коммуникативный подход для определения и сопоставления содержания стратегии 


\section{МАТЕРИАЛЫ И СООБЩЕНИЯ}

продвижения территорий в Европе и России, прагматических установок авторов, вербальных и невербальных средств их реализации, использующихся на туристических сайтах, в социальных сетях и блогах.

Стратегия брендирования территории формирует определенные культурные образы, ассоциации, смыслы с помощью тактик, реализуемых невербальными и вербальными средствами с учетом внешнего контекста, прагматических установок участников. Под стратегией брендирования мы понимаем план достижения общих (формирование положительного образа в коллективном воображении лингвосоциума и др.) и частных (знакомство с определенным мероприятием, достопримечательностью и др.) целей, выстроенный с учетом аудитории, детерминирующий выбор канала коммуникации, тактик построения бренда, невербальных и вербальных средств реализации. Выбор коммуникативной стратегии обусловлен внешними факторами, в первую очередь финансовыми возможностями, и условиями реализации. Ее воплощение закрепляется за определенными государственными институтами и коммерческими организациями. В данной работе применяется подход, при котором коммуникативная стратегия характеризуется как макроили микро-стратегия (см. таблицу).
Туристические сайты, посты в социальных сетях и блоги являются цифровым продуктом реализации микро- или макро-стратегии брендирования. Благодаря аудиовизуальным возможностям Интернета, как ключевого канала продвижения территориального бренда, используются фото-, видео- и аудиоматериалы и сопровождающий их текстовый контент. Важную роль при этом играет языковая составляющая стратегии продвижения с определенным инструментарием и технологиями, которые применительно к территориальным брендам могут быть также эффективны, как и в любой другой рекламной кампании.

\section{Результаты и обсуждение}

\section{Механизмы брендирования \\ на туристических сайтах малых городов России}

В вопросах брендирования большинство малых российских городов являются аутсайдерами. Однако есть и удачный опыт реализации этой стратегии, например при продвижении территорий двух городов Волгоградской области: Урюпинска (41 594 жителя) и Камышина (110 318 жителей).

\section{Различия коммуникативных стратегий продвижения территорий}

Differences in communication strategies for promoting territories

\begin{tabular}{|l|l|l|}
\hline \multicolumn{1}{|c|}{$\begin{array}{c}\text { Критерий } \\
\text { разграничения }\end{array}$} & \multicolumn{1}{|c|}{ Микро-стратегия } & \multicolumn{1}{|c|}{ Макро-стратегия } \\
\hline Структура бренда & $\begin{array}{l}\text { Разрозненная, привязана к локальному } \\
\text { событию или достопримечательности, не } \\
\text { подкреплена значительными историче- } \\
\text { скими фактами или прецедентными } \\
\text { именами }\end{array}$ & $\begin{array}{l}\text { Единая, основана на исторических собы- } \\
\text { тиях, подкреплена дополнительными } \\
\text { универсальными компонентами, вписы- } \\
\text { вающимися в общий блок (событийны- } \\
\text { ми, кулинарными, ремесленными и т. д.) }\end{array}$ \\
\hline Канал коммуникации & $\begin{array}{l}\text { Локальный Интернет, местные СМИ, } \\
\text { эпизодическое использование федераль- } \\
\text { ных и международных каналов }\end{array}$ & $\begin{array}{l}\text { Глобальный Интернет, общегосударст- } \\
\text { венные СМИ, международные туристи- } \\
\text { ческие сайты }\end{array}$ \\
\hline Язык коммуникации & $\begin{array}{l}\text { Преимущественно русский (моноязыч- } \\
\text { ная коммуникация) }\end{array}$ & $\begin{array}{l}\text { Язык страны, соседних территорий и } \\
\text { стран, а также мировые языки (англий- } \\
\text { ский, китайский и др.) (полиязычная } \\
\text { коммуникация) }\end{array}$ \\
\hline $\begin{array}{l}\text { Целевая аудитория } \\
\text { Присутствие в соци- } \\
\text { альных сетях }\end{array}$ & $\begin{array}{l}\text { Жители крупных городов региона и со- } \\
\text { седних регионов (внутренний туризм) }\end{array}$ & $\begin{array}{l}\text { Жители крупных городов страны и других } \\
\text { стран (внешний и внутренний туризм) }\end{array}$ \\
\hline $\begin{array}{l}\text { Государственнование микроинфлюенсеров } \\
\text { держка погеров с количеством подписчиков от } \\
\text { ста до нескольких тысяч) }\end{array}$ & $\begin{array}{l}\text { Использование макроинфлюенсеров (по- } \\
\text { пулярных лиц, блогеров с количеством } \\
\text { подписчиков более десяти тысяч) }\end{array}$ \\
\hline
\end{tabular}


Урюпинск имеет свой официально зарегистрированный товарный знак-Столища российской провинции и Столица российской глубинки. Подробнее о его создании см.: [Королькова, Наумова, 2018].

Камышин претендует на звание Арбузной столицы России, о чем заявлено на странице города на национальной туристической платформе «Russian Open». Этот товарный знак проходит сейчас процедуру официальной регистрации.

В отличие от Урюпинска, бренд которого опирается на существующий о городе миф, толчком для разработки камышинского бренда стало включение города во всероссийский туристический проект в качестве самого арбузного города России: местные жители убеждены в исключительных вкусовых качествах выращиваемых здесь арбузов, кроме того, согласно городской легенде местный сорт арбузов высоко оценил Петр I, оказавшийся на этих территориях во время Персидского похода (1722 г.). С 2007 г. при поддержке городских властей в Камышине проходит Арбузный фестиваль. Следовательно, вербальная номинация Арбузная столииа России отражает внутреннее видение города (городская самоидентичность), подкрепленное необычным событием - Арбузным фестивалем, который может привлечь не только местных жителей, но и туристов из других городов. Для того чтобы данная номинация стала брендом, необходимо сформировать ее восприятие извне, то есть имидж города, что позволило бы говорить о созданном бренде и потенциале его коммерциализации. На примере нескольких интернет-платформ рассмотрим, как реализуется коммуникативная стратегия продвижения этой территории.

Сайт «Уголок России. Камышин и Нижнее Поволжье» - авторская площадка местного жителя Леонида Смелова (http:// kamyshinstar.ru) - посвящен истории Камышина, его достопримечательностям и различным городским событиям. Он высоко информативен, его целевой аудиторией являются любители истории, краеведы, но не туристы, поскольку на его страницах расположено мало визуально аттрактивной информации - фотографий и изображений. Это снижает привлекательность сайта. Целевая аудитория опре- делена авторской тактикой: рассказывая об Арбузном фестивале, Л. Смелов в первую очередь упоминает исторические факты, ставшие обоснованием его организации; представляя фестивальную программу, прибегает к аллюзии на знаменитый советский фильм 1986 г. «По главной улице с оркестром»-каждый участник (человек, семья или коллектив) может стать иентром праздника, отшагать «по главной улице с оркестром», использует книжные метафоры, понятные подготовленной аудитории - «Красное» прошлое кануло в Лету. При этом основной акцент делается на историческом компоненте, а не целостном бренде территории.

Сайт «Russia Open: национальный туризм» (http://www.russia-open.com/rus/regions/ south/volgograd/TurMarVolgograd/KamishinCity/ index.phtml) - национальная туристическая платформа, являющаяся российской частью глобального интеграционного проекта Eurasia Open, - направлен на развитие туризма на территории страны и постсоветском пространстве. Целевая аудитория - русскоговорящие пользователи из бывших советских республик. Сайт функционален и информативен: некоторые достопримечательности города и его окрестности представлены на фотографиях хорошего качества, но небольшого размера и в малом количестве. Текст формирует привлекательный образ в коллективном воображении лингвосоциума, насыщен лексикой, выражающей положительную оценку: замечательное строение; восхищает своей красотой и оригинальностью исполнения; гармонично дополнен; коллекция книг обширнейшая; парк вышел потрясающе красивым; очаровательных кустарников и деревьев; описывает красоту окрестностей Камышина: неповторимые виды; уникален по характеру своего ландшафта; чистейшая ключевая вода; увлекательный танеи теней под аккомпанемент природной «музыки»; множество редких и даже вымирающих видов животных; камнях многомиллионного возраста. Однако главное для города туристическое событие - Арбузный фестиваль - упоминается только раз: Город $\mathrm{Ka}$ мышин Волгоградской области даже является "Арбузной столицей России» и ежегодно на его территории проходит 


\section{МАТЕРИАЛЫ И СООБЩЕНИЯ}

Арбузный фестиваль. Следовательно, на создание бренда Камышина сайт не нацелен.

Сайт «Dostoprimechatelnosti-M» (https:// dostoprimechatelnosti-m.ru/dostoprimechatelnostikamyshina-spisok-foto-i-opisanie) - российская туристическая платформа - адресован русскоязычным пользователям Интернета, являющимся потенциальными путешественниками. Именно он благодаря удачному сочетанию визуальных и текстовых компонентов превращает Камышин в аттрактивную туристическую дестинацию и обеспечивает позитивное моделирование реальности. Прежде всего сайт формирует в коллективном сознании прямую связь между городом и знаковой русской рекой Волгой: В Волгоградской области протекает великая русская река Волга. Именно на правом берегу этой величавой красавииы раскинулся древний город Камышин. Здесь делается акцент на таких достоинствах малых городов, как живописная природа и гостеприимные жители: Гостеприимные горожане с радостью расскажут и покажут все изюминки своей местности. На уровне лексики следует выделить языковые единицы, номинирующие Камышин как тихое, спокойное место, подходящее для беззаботного отдыха, где шикарные закаты, вековые хвойные деревья, чистый и ароматный воздух, шикарные иветники. В городе есть и культурная составляющая, интересная туристам: уникальные экскурсии и настоящий двореи в стиле русского барокко. Презентуя такую доминанту имиджа провинции, как природа, авторы используют лексику, гиперболизирующую положительную оценку: неподражаемая природная достопримечательность; мощные плиты квариевого песчаника; будут очарованы Щербаковским парком; феноменальность парка; исключительная история. Как и на ресурсах, описанных выше, на данном сайте только раз упоминается о ключевом для брендирования событии и связанном с ним местном продукте: $B$ начале сентября в $\mathrm{Ka}$ мышин съезжается огромное количество туристов, а участники Арбузного фестиваля с радостью угощают всех сочными арбузами и дынями.

Итак, все перечисленные сайты имеют цель привлечь туристов, формируют положи- тельный образ территории, но не создают бренда города. Информация, представленная на них, не выделяет Камышин из многих других провинциальных городов России, поскольку не обозначает опредмечивающего его исключительность символа, вокруг которого строится культурно-историческая и событийная среда города. Кроме того, практически отсутствует когнитивная и эмотивная информация о ключевом событии, которое связано с символом города.

Многие исследователи брендов территорий отмечают, что событийный туризм - это важный, если не ключевой, компонент для малых городов, которые не могут предложить путешественникам богатой архитектуры, не имеют интересной культурной среды [Визгалов, 2011; Митягина, 2018; и др.]. Как подчеркивает Д.П. Долженко, событийный туризм «связан с разнообразными значимыми общественными событиями, а также природными явлениями, привлекающими своей уникальностью, экзотичностью, неповторимостью большое количество соотечественников и туристов из зарубежных стран. Блок событийного туризма включает в себя ряд мероприятий культурного, спортивного, этнографического, выставочного (делового) видов туризма» [Долженко].

У Камышина есть свой опредмеченный символ - арбуз, а событие, напрямую связанное с ним - Арбузный фестиваль, поскольку город позиционирует себя Арбузной столиией России.

Главное (в аспекте брендирования) событие, происходящее в Камышине (Арбузный фестиваль), представляют два сайта: «Все про Арбузы» (http://pro-arbuz.ru/arbuznoe/arbuznyjfestival-v-kamyshine) и «Arbuzfest» (https:// arbuzfest.ru). «Все про Арбузы» посвящен apбузу, его уникальным качествам, истории, содержит рекомендации по выращиванию этой ягоды, рассказывает об арбузных фестивалях в мире, в том числе и про камышинский фестиваль. Текст сопровождается качественными фотографиями, передающими атмосферу события.

Сайт «Arbuzfest» принадлежит Комитету культуры г. Камышина и полностью посвящен Арбузному фестивалю, что свидетельствует о понимании властями города значи- 
мости бренда территории для успешного развития туризма. Нацеленность сайта на формирование бренда города проявляется в цветовом оформлении (красно-зеленые тона), выборе визуальных компонентов и тексте. Как отмечает А.А. Гуреева, в тексте, реализующем стратегию брендирования, «необходимо описать возможность обрести уникальный опыт, находясь на территории» [Гуреева, 2018, c. 36]. Опыт должен быть связан с опредмеченным символом бренда.

Организаторы фестиваля и создатели его сайта проявили лингвокреативность, обыграв номинацию арбуз и слова, обозначающие части этого плода, в названиях мероприятий, включенных в программу: Арбузное дефиле, Арбузный парад, Арбуз-экспо, АРТ-бузная корка, Арбузный боулинг, Арбузный карнавал, Арбузные фантазии, Арбузный сувенир, Арбузные малыши, Большие арбузные гонки, Арбузная олимпиада, Арбузные обжор$\kappa и$, Летающие корки, Летающие дольки. Если бренд - это совпадение самоидентичности (внутреннее восприятие себя) и имиджа (видение извне), то закономерно, что авторы именуют жителей города городская арбузная нация, город - арбузным градом, арбузной столицей, арбузным краем. Реализуя стратегию брендирования, создатели сайта манипулируют прецедентными единицами, позволяющими включить новое туристическое событие в общий культурный фонд, играя с лексическими единицами, составляющими фоновое этнокультурное пространство. Так, жителям России хорошо известны номинации Волга - матушка, Дон - батюшка, соотносящиеся с двумя главными реками страны. Авторы сайта создают собственные номинации Волга-матушка, арбуз - батюшка, что способствует формированию доброжелательного отношения к городу со стороны как внутренних, так и внешних потребителей туристических услуг.

«Arbuzfest» обладает рядом достоинств: продуманная структура и визуальный ряд, отсылающие к арбузу; качественные иллюстрации; графическое сопровождение (например, схема мероприятия), высокая информативность текста. Коммуникативные тактики реализации стратегии продвижения территории характеризуются здесь активным использо- ванием разговорной лексики (ого-го!, офигеть, обжорка, отчаливает от улицы и т. д.), образных эпитетов (яркий сочный праздник, красочные платформы, незабываемый арбузный праздник, потрясающий величием парад и др.) и отсылок к прецедентным текстам при описании мероприятий Арбузного фестиваля (Автомобиль - роскошь!, Покупай, торопись!).

Таким образом, при продвижении малых городов России используется микро-стратегия, бренд распространяется на хорошо сегментированную аудиторию, представляющую собой ограниченое количество пользователей внутренних туристических продуктов, акцент делается на значимых для территории событиях. Лингвопрагматический потенциал текстов реализуется высокоинформативной их подачей, которая не исключает эмоциональности и оценочности.

\section{Механизмы брендирования на туристических сайтах малых городов Европы}

Почти все города Европы, как большие, так и малые, продвигают свои исторические бренды, учитывая средневековое наследие, что объясняет выбор «опорных точек», определяющих вектор продвижения территорий.

Проанализируем, как реализуется стратегия продвижения провинциального бельгийского городка Брюгге (около 100 тыс. жителей), находящегося в 54 км от Брюсселя, на таких туристических платформах, как «Visiter Bruges.com» (http://www.visiterbruges.com), «Bruges Tourisme» (https://www.brugestourisme.com), "Voyages Michelin» (https://voyages.michelin.fr).

Сайты используются европейцами, поэтому имеют версии на нескольких языках с целью повышения аттрактивности продвигаемой территории. При описании акцент туристического маршрута в Брюгге делается на географическом положении города, его близости к морю и большом количестве каналов, откуда сравнение с Северной Венецией: Que serait Bruges sans ces canaux? Certainement pas la ville que l'on connaît aujourd'hui. L'histoire de la "Venise $d u$ Nord» est intrinsèquement liée à ses canaux : ce sont eux qui ont facilité son ascension fulgurante au 
moyen âge et ce sont eux aussi qui ont petit à petit réduit son influence lorsque l'ensablement des canaux empêcha les bateaux de parvenir jusqu'au coeur de la cité - Чем был бы Брюгге без этих каналов? Конечно же, не тем городом, который знают сегодня. История «Северной Венеции» неотъемлемым образом связана с этими каналами: это они обеспечили городу молниеносный подъем в Средние века, но и они же уменьшили влияние Брюгге, когда их «запесчанивание» стало мешать кораблям заходить в сам город» (здесь и далее перевод с французского О.И. Поповой).

Мысль об исключительной важности каналов для города и его истории выражается с помощью описательных оборотов pas la ville que l'on connait aujourd'hui, l'histoire est liée à ses canaux. Подчеркивается роль каналов как экономического фактора, дающего развитие городу и региону (Брюгге превратился в успешную торговую столицу в начале XII века): ont facilité son ascension fulgurante, ont...réduit son influence: Bruges devint une capitale commerciale dès le 12e s.

Достопримечательности Брюгге представлены опосредованно, через каналы: Églises, monuments civils, maisons furent construits autour de ses nombreux canaux, qui lui donnent son surnom de Venise du Nord Церкви, памятники, дома были построены вокруг многочисленных каналов, которым город обязан своим вторым «негласным» именем «Северная Венеция».

Прогулки по каналам позволяют узнать город с разных сторон, увидеть то, что невозможно рассмотреть, находясь на маленьких улочках: voir la ville différemment, de belles façades sont invisibles... depuis des ruelles. Каналы являются внутригородской транспортной артерией, а набережные вдоль них дают возможность велосипедистам быстро передвигаться по городу и за его пределы и не зависеть от дорожного движения: longer des canaux... permet de rejoindre les villes proches... sans subir la circulation automobile ou le bruit.

Тема значимости каналов - основа стратегии продвижения бренда города. Коммуникативные тактики ее реализации включают использование прямых положительных номи- наций: réjouir les visiteurs (радовать посетителей), des canaux soient calmes, profonds et larges (каналы должны быть тихими, глубокими, широкими), se balader le long de ces canaux est agréable (прогулки по каналам это приятно).

Для продвижения бренда «Брюгге» туристические сайты уделяют внимание событийному туризму - Процессии Святой Крови в день Вознесения: Bruges est réputée pour... les festivités célébrées le jour de l'Ascension avec la procession du Saint-Sang.

С одной стороны, наблюдаются схожие событийные тактики продвижения бренда малого города в ходе реализации стратегии в России и Европе, с другой - отмечаются значительные отличия в происхождении референтных праздников. В Брюгге событие связано со средневековой историей, что акцентируется на официальном туристическом сайте города, который называет Брюгге стоящим одной ногой в Средневековье, а второй - в современности: avec un pied dans le Moyen Age et l'autre bien ancré dans le présent (http:// www.visiterbruges.com). Праздник в Брюгге имеет религиозную основу и отмечается масштабно с 1304 г. торжественной процессией со Святыми Дарами, хоругвями и свечами. Процессия Святой Крови Христовой входит в список культурного наследия ЮНЕСКО.

Культурной опорой стратегии бренда Брюгге является также фламандская живопись: Bruges est réputée pour être berceau de la peinture flamande - город известен как колыбель фламандской живописи, он отражен в произведениях Яна ван Эйка, Рогир ван дер Вейдена, Ганса Мемлинга и др. Работы знаменитых примитивистов являются референтной основой узнаваемости Брюгге в мире и освещаются на всех туристических сайтах. Примечательно, что на национальном сайте «Visiter Bruges» вся информация представлена на пяти языках: фламандском, французском, немецком, английском и испанском. Коллекцию всемирно известных полотен художников - шедевры фламандского экспрессионизма - в музее Греннинге сайт называет основной «точкой притяжения»: les ponts d'orgue d'une visite. Визуальные тактики актуализируют текстовую информацию о фактах истории посредством четких, привлекающих вни- 
мание заголовков Paradis en un coup d'oeil (Рай за одно мгновенье), Jan van Eyck à Bruges (Ван Эйк в Брюгге), представляя изображения средневекового здания музея и фото некоторых известных картин.

Все рассматриваемые туристические сайты активно развивают гастрономическую тему, опираясь при этом на местные реалии [Попова, 2016], например национальное блюдо картошку-фри (frites). Информативно представленная история блюда и музея картошки-фри визуально поддерживается качественными изображениями продукта, экспозиции и здания музея. Акцент делается на уникальности музея, исторической и архитектурной ценности этого строения: le musée de la frite est le seul au monde consacré à l'histoire de la pomme de terre et de la frite (музей картошки-фри - единственный в мире, посвященный истории картофеля); le plus ancien bâtiment de la ville et l'un des plus beaux (одно из древнейших и красивейших зданий). Вклад в создание коллективного образа гастрономической картофельной столицы вносят аттрактивные заголовки. Например, материал о коллекции приспособлений, используемых для сбора урожая, дальнейшей его переработки, сортировки и приготовления продукта назван $C$ 'est une experience culturelle amusante et gourmands pour petits et grands! (Это забавный и вкусный опыт познания культуры для маленьких и взрослых!). Гастрономическая часть бренда города представлена также шоколадом, поскольку Брюгге причисляют к самым шоколадным городам мира и считают родиной пралине: Parlez avec des experts des valeurs nutritionnelles et des bienfaits $d u$ chocolat pour la santé (Поговорите с экспертами о питательной ценности шоколада и его пользе для здоровья); Découvrez les vrais saveurs $d u$ chocolat belge avec cette expérience goumande (Откройте для себя истинные вкусы бельгийского шоколада, используя этот вкусный опыт).

Итак, брендирование малых городов Европы осуществляется посредством макростратегий, однако при этом используются схожие преимущественно коммуникативные тактики информирования. Сайты направлены, вопервых, на предоставление актуальной информации, изложенной как в нейтральном, так и эмоциональном тоне, создаваемом единицами лексического и синтаксического уровней, во-вторых, на реферативное изложение сведений о территории с комментариями авторов, употребляющих в большинстве случаев нормативные языковые средства. Субъективные оценки города отражены умеренно и служат для актуализации фактов, рекомендаций и инструкций по посещению. Тексты содержат фоновую и прецедентную лексику, которая отсылает к памятникам культуры и событиям истории. Частое использование наречий и прилагательных подтверждает грамматическую зависимость рекламных текстов от прагматической направленности (подробно об этом см: [Попова, 2018]). Преобладают сложноподчиненные предложения с многочисленными придаточными; как средства аттракции употребляются риторические вопросы.

\section{Брендирование малых городов в блогах и социальных сетях}

Благодаря тому, что интернет-пространство с начала 2000-х гг. стало ориентированным на интеракцию, динамическую коммуникацию (блоги, соцсети, wiki-проекты и т. д.), одним из распространенных путей продвижения территориального бренда стали социальные сети, блоги, посты и комментарии на глобальных туристических платформах, передающие оценку известных или влиятельных в той или иной области лиц, а также рядовых туристов, посетивших какую-либо территорию. Как отмечает Б. Вирц, сеть превращается в средство масс-медиа, в котором пользователи все больше определяют содержание информации. Они объединяются, производят новую информацию и предоставляют ее другим пользователям [Митягина, 2018, с. 8].

Согласно современным исследованиям (см., например: [Булетова, Степанова, 2019; Buletova, Zlochevsky, Stepanova, 2017; Huff, 2017; Oleynik, Stepanova, 2019; What Are the Top Influencer Marketing...]), преимуществами привлечения указанных выше ресурсов к продвижению бренда являются: относительно небольшие финансовые затраты; быстрое формирование лояльности к бренду; возможность привлечения новых постоянных клиентов; высокая эффективность, поскольку пользовате- 
ли добровольно подписываются на данный ресурс; таргетирование продукта для широкой или нишевой аудитории в зависимости от типа кампании; создание оригинального контента, который обогащает интернет-маркетинг, а также выходит за пределы цифровой среды.

Как показал анализ, социальные сети практически не участвуют в создании и продвижении территориального бренда г. Камышина. Поскольку событием-драйвером бренда является Арбузный фестиваль, то закономерно, что в VK и Instagram существуют группы «Камышинский арбузный фестиваль» (https://vk.com/arbuzfest_kam-369 участников; https://www.instagram.com/arbuznyfestival/ ?hl=en -205 подписчиков). На этих ресурсах в основном размещены фотографии с прошедших фестивалей, но почти отсутствует текст. Интересен тот факт, что посты об Арбузном фестивале представлены на сайте «Отзовик» (https://otzovik.com/reviews/arbuzniy_festival russia kamishin), где публикуются отзывы на все, что продается или можно увидеть, и в социальных сетях с четкой целевой аудиторией - женские социальные сети - «MyJulia.Ru» (http://www.myjulia.ru/post/431794) и «Babyblog» (https://www.babyblog.ru/community/post/travel/ 3050601). Здесь можно встретить отзывы как туристов, посетивших фестиваль, так и местных жителей.

Если ресурс «MyJulia.Ru», как и перечисленные выше, дает только яркий и красочный фотоотчет о событии, то на других сайтах («Отзовик» и «Babyblog») представлены свойственные для Рунета тексты, реализующие микро-стратегию брендирования: эмоционально-оценочная характеристика события с ярко выраженными субъективными оценками, поскольку отзыв оставлен обычным человеком, делящимся значительной частью своей повседневной жизни с подписчиками. Для пользователей с «Babyblog» характерно употребление эмотивных и субъективно-оценочных средств: возьмет вас за душу своим тепльмм приемом, широтой души и арбузной щедростью; очень ярко и красочно; Об этом Празднике можно было рассказать так тепло и нежно; это такое теплое отношение к родному городу, которое трудно передать словами. Формат социальной сети позволяет легко вступать в контакт с це- левыми группами, распространяя желательную информацию, и получать «feed back», поскольку у адресантов есть возможность выразить свое мнение, оставить комментарий, а также ссылки на дружественные ресурсы.

При продвижении российских малых городов посредством блогов, соцсетей и под. реализуются микро-стратегии. Они, как правило, основаны на тактике позиционирования территории как направления, куда можно отправиться всей семьей, несколькими поколениями одновременно. Российские малые территории чаще продвигаются индивидуальными блогерами, реже - известными людьми и путешественниками (например, М.Ю. Сегал), преимущественно для соотечественников рекламирующими событийный туризм как составляющую бренда городов, не отличающихся архитектурными, историческими, культурными традициями.

Михаил Юрьевич Сегал, российский киноактер, кинорежиссер, писатель, в своем блоге на портале Самараинтур (https://www. samaraintour.ru/13688) разместил пост Автомобильные круизы или как я провел лето. Камылиин. Пост выполнен в форме эссе-повествования, в котором автор делится впечатлениями и дает рекомендации для посещения. Город позиционируется им как интересная туристическая дестинация: Камышин - это мой город - открытие 2010 года, где есть что посмотреть; Это подтверждает большое количество купеческих особняков, сохранившихся в иентре города; Четыре с лишним километра набережной ограждены ажурными чугунными решетками; Камышин очень хорошо смотрится с Волги. Риторические вопросы вовлекают читателей в прямой диалог: Посидеть так теплым летним вечером после долгой дороги в компании приятных людей - что может быть лучше?

На блоге волжанина «Volgabest» (23 подписчика), в сообществе «Камышин и Камышане», представлена серия публикаций о Камышине и его достопримечательностях (https://volgabest.livejournal.com/tag/камышин). Благодаря фотографиям разных возрастных и социальных групп жителей и гостей Камышина, а также текстовой части город позиционируется как направление, куда можно от- 
правиться всей семьей: очень симпатичный, ухоженный парк, куда можно направиться всей семьей с детьми; Останавливались в палатках с детьми. Событийному туризму (Арбузный фестиваль) посвящен раздел Жили-были... камышане с красочными фотографиями и видео, представляющими событие глазами жителей города. Блог характеризуется активным использованием разговорной лексики, встречаются ненормативные языковые употребления, а также множество субъективно-оценочных средств: Как говорят, Швейцария в Волгоградской области; Быть в Камышине и не прогуляться по набережной, это не есть гут! - а прогулялся, плюсик заработал! При этом автор также отмечает и негативные впечатления от посещения города: Все заброшено, бетон в вblбоинах, куча разбитых бутылок, опять же торчашие железки; В общем, очень-очень грустно; Неплохой южный городок находится в таком упадке; Ужасное впечатление о музее и его сотрудниках.

Как видим, оба блога содержат исторические, культурные, гастрономические факты, однако не направлены на формирование целостного имиджа территории.

Продвижение европейских малых городов, как правило, осуществляется через национальные порталы блогов, групповыми блогерами и отдельными известными людьми и путешественниками, имеющими более 40000 подписчиков, но достигшими своей популярности не в социальных сетях. Так, официальный англоязычный портал блогов о Брюгге «Visit Bruges» (https://visit-bruges.be) - бельгийская культурная туристическая платформа, которая поддерживается министерством туризма и направлена на развитие туристического сектора в экономике - включает множество постов профессиональных блогеров о культурных, исторических памятниках, достопримечательностях, фестивалях, гостиницах, ресторанах, погоде, содержит практические рекомендации и отзывы посетителей. Основная стратегия продвижения города выражена слоганом: A tourist blog for a world heritage city Туристический блог города Всемирного наследия (здесь и далее перевод с английского Е.В. Степановой). Целевая аудитория - англоговорящие туристы со всего мира. Сайт функционален и информативен, содержит большой раздел City in Photos (Город в фотографиях) с качественными иллюстрациями. Тексты постов создают в коллективном воображении лингвосоциума образ средневекового, но современного города с богатым культурным наследием: The old medieval buildings and churches testify to a grand and glorious past; But in addition you also have cozy corners and squares, the beguinage, the Lake of Love, Lovers bridge, flea markets, courtyards, almshouses, ramparts, concerts, many small canals and bridges - Старые средневековые здания и церкви свидетельствуют о великом и славном прошлом; но кроме того, вы можете посетить уютные уголки и площади, бегинаж, Озеро Любви, мост Влюбленных, блошиные рынки, дворы, богадельни, крепостные валы, концерты, множество маленьких каналов и мостов. Портал направлен на формирование бренда города, содержит большое количество фактической информации, использует те же номинации, что и официальные туристические сайты: canals (каналы), bridges (мосты), medival (средневековый) и др.

Блог «On the Luce Travel Blog» (https:// www.ontheluce.com) является одним из примеров продвижения европейских территорий в интернет-пространстве. Его автор Люси из Челтенхэма (Великобритания) превратила путешествия в работу, посещая различные города и описывая их в своем блоге. Сведения в разделе, посвященном Брюгге, в формате дневника отражают историю города, гастрономические и культурные достопримечательности. Раздел информативен, адресаты постов - любители путешествий, туристы. Блог дополнен визуально привлекательными изображениями и видеороликами. Целевая аудитория детерминирована блогером: туристы, приезжающие в город на выходные, планирующие оставаться не более трех дней. Люси описывает с минутной точностью способы добраться в Брюгге из Брюсселя и передвижение внутри города. Отдельная страница блога посвящена гастрономическим возможностям города. Автор упоминает рестораны и кафе, предлагающие бельгийские блюда и напитки с местной спецификой подачи и рецептурой: Head to Tom's Diner for dinner, an informal spot serving international dishes 
made with local ingredients, like Ardennes tenderloin and stuffed zucchini; Try a hot chocolate and a pancake oozing with Nutella from the crêpe stall - and if you're feeling energetic you can walk back into Bruges along the canalside path - Отправьтесь на ужин в закусочную Tom's Diner - неформальное место, где подают блюда интернациональной кухни, приготовленные из местных ингредиентов, такие как арденнская вырезка и фаршированные кабачки; попробуйте в палатке горячий шоколад и блины, щедро сдобренные шоколадной пастой, и если вы чувствуете в себе достаточно сил и энергии, прогуляйтесь до Брюгге по тропинке вдоль канала. Акценты делаются на кулинарных и туристических достопримечательностях, что соответствует общему бренду территории, но не полностью раскрывает его.

В блоге Ронды и Майка - любительском блоге путешественников - большое внимание уделяется профессиональным фотографиям, которые сопровождаются комментариями и короткими историями. Пост, посвященный Брюгге, отличается большой содержательной частью и написан в форме эссе, лейтмотив которого - фильм режиссера Колина Фаррелла «В Брюгге», привлекший внимание автора и заставивший его посетить город: The film did a great job of showcasing Bruges, so much so, that I couldn't stop dreaming about it for weeks - В фильме прекрасно показан Брюгге, поэтому в течение нескольких недель я не мог расстаться с мечтой посетить этот город. В структуре блога используется сравнение ожиданий после просмотра фильма и реальных впечатлений от города. Информативно и образно описывается посещение исторических памятников, при этом всегда прослеживается личность автора, его предпочтения и интересы: After only one day in Bruges, I was convinced that it was one of the MOST BEAUTIFUL CITIES IN EUROPE; I love buildings with character and colour, so the hugest smile came on my face when I stepped out from under the Belfry into the market square - Проведя всего один день в Брюгге, я убедился, что это один из самых красивых городов Европы; мне нравятся здания с характером и цветом, поэтому самая широкая улыбка появилась на моем лице, когда я вы- шел из-под колокольни на Рыночную площадь. В текстах использованы нейтральные и эмоционально окрашенные лексические единицы: While the carillon was interesting to watch, the best part of the belfry was the panoramic views you get of Bruges; It's just amazing! - Колокольный перезвон был удивительным и интересным, но, пожалуй, больше всего нам понравился панорамный вид, который открывается на город из колокольни. Это просто потрясающе!; содержатся рекомендации, выраженные повелительными конструкциями: Do take a boat tour; Avoid eating at Grote Markt and Burg square - Настоятельно рекомендуем заказать лодочную экскурсию; однако не обедайте на Гроте-Маркт и Бург-сквер. В отличие от культурно-исторической специфики, гастрономической тематике уделяется недостаточно внимания - упоминается только шоколад: The chocolate in Bruges was the best we had in Europe and I eat A LOT of chocolate - Шоколад в Брюгге был самым лучшим, из тех, которые нам удалось попробовать в Европе, а я ем действительно МНОГО шоколада.

Как видим, продвижение малого европейского города посредством блогов и социальных сетей осуществляется в рамках макро-стратегии брендирования территории.

\section{Заключение}

Изучение туристических сайтов, блогов и постов на таких площадках, как YouTubers, Twitter, Instagram, LiveJournal и др. показало, что для европейского интернет-пространства характерно использование макро-стратегии брендирования. Каналы коммуникации включают интернет-платформы территорий и достопримечательностей, социальные сети, блоги, которые передают единый положительный и непротиворечивый образ территории. Для охвата брендом большей аудитории потенциальных клиентов существенное значение имеет участие опытных путешественников или известных людей, которые делятся опытом и рассказывают не только об эксклюзивных, немассовых продуктах, но и возможностях культурно-исторического или экологического туризма, демонстрируя социально ответственный подход. Типичной при брендировании ев- 
ропейских городов является тактика информирования, реализуемая разнообразными языковыми и визуальными средствами. При этом и на туристических сайтах, и в блогах используются одни и те же ключевые для бренда территории номинации. Тактика информирования направлена на предоставление актуальных фактов посредством преимущественно нейтрального изложения фактов, реферативного предоставления сведений о территории из первоисточника, добавления лаконичных или развернутых нейтральных комментариев, нормативного употребления языковых средств.

Брендированием российских малых городов, как правило, занимаются обычные люди, живущие одной жизнью с подписчиками, количество которых колеблется от 20 до 10000 человек. Туристические сайты, посты и блоги не всегда имеют общую цель - продвижение бренда города. Посты, описывающие мероприятия культурного, спортивного, этнографического, выставочного характера, размещаются в основном в социальных сетях местными жителями, реже о них пишут блогеры и известные люди. При продвижении российских малых городов реализуются микро-стратегии. Они, как правило, основаны на тактике позиционирования территории как направления, куда можно отправиться всей семьей, несколькими поколениями одновременно. При этом деятельность российских блогеров не всегда вписывается в единую стратегию продвижения страны или территории. Типичной при брендировании российских городов является тактика эмоциональной оценки, которая имеет целью отражение отношения автора к предмету сообщения, реализуется посредством эмоциональных, ненормативных, субъективно-оценочных языковых средств.

Значимой поддержкой для создания и продвижения бренда российских малых городов могла бы стать более активная вовлеченность в этот процесс известных российских блогеров и путешественников, как это реализуется в европейском контенте, поскольку в XXI в. возрастает роль таких каналов информирования, как блог, соцсеть и т. п. Перефразируя известный афоризм «если события нет в интернете, то его нет вообще», можно конкретизировать его значение: «если о событии не говорят в социальных сетях, то его нет». Полезным для формирования позитивного имиджа малого города на национальном и международном уровнях было бы более активное внедрение макро-стратегий брендирования в рамках единого государственного фирменного стиля, а также использование исторических, культурных, экологических, гастрономических факторов в качестве его основы. Продвижению бренда способствовала бы реализация стратегии на нескольких иностранных языках, например, английском и китайском, с использованием информативных и коммуникативных тактик на официальных порталах территорий и в социальных сетях.

\section{СПИСОК ЛИТЕРАТУРЫ}

Булетова Н. Е., Степанова Е. В., 2019. Сравнительный анализ эволюции египетской и российской экономических систем // Политическое пространство и социальное время : Правда и ложь в политике и искусстве : сб. науч. тр. XXXVI Междунар. Харакского форума. Симферополь : Ариал. С. 41-46.

Визгалов Д. В., 2011. Брендинг города. М. : Ин-т экономики города. $160 \mathrm{c}$.

Гуреева А. А., 2018. Маркетинговая функция текстов территориального брендинга // Ното Loquens : (Вопросы лингвистики и транслятологии) : сб. ст. Волгоград : Изд-во ВолГУ. Вып. 11.С. 34-40.

Долженко Д. П. Опыт разработки классификации современного российского туризма. URL: http://www.intacadem.ru/statji/dolzhenko-g.p.opyt-razrabotki-klassifikatsii-sovremennogorossiyskogo-turizma.html (дата обращения: 07.11.2019).

Королькова С. А., Наумова А. П., 2018. Брендинг малых городов: лингвистические и прагматические аспекты // Коммуникативные, номинативные и транслатологические аспекты территориального брендинга. Волгоград : Изд-во ВолГУ. С. 65-81.

Митягина В. А., 2018. Дискурс маркетинга территорий в коммуникативном пространстве WEB 2.0 и WEB 3.0 // Homo Loquens : (Вопросы лингвистики и транслятологии) : сб. ст. Волгоград : Изд-во ВолГУ. Вып. 11. С. 3-17.

Попова О. И., 2016. Перевод реалий текстов туристического дискурса // Академическая наука проблемы и достижения : материалы X Междунар. науч.-практ. конф. Северный Чарлстон : [б. и.]. Т. 2. С. $151-156$. 
Попова О. И., 2018. Стилистические средства текстов туристического брендинга города // Коммуникативные, номинативные и транслатологические аспекты территориального брендинга. Волгоград : Изд-во ВолГУ. С. 82-96.

Шафранская И. Н., 2012. Стратеги брендинга в территориальном маркетинге. URL: https://www. hse.ru/data/2012/09/28/1244118907/Shafranskaya Strategii.pdf(дата обращения: 17.12.2019).

Anholt S., 2009. Places: Identity, Image and Reputation. Palgrave Macmillan : [s. n.]. 168 p.

Braun E. City Marketing: Towards an Integrated Approach. URL: https://repub.eur.nl/pub/13694 (date of access: 17.12.2019).

Buletova N. E., Zlochevsky I. A., Stepanova E. V., 2017. Structural Analysis and Criteria for Assessment of State Economic Policy // International Journal of Applied Engineering Research.Vol. 12, № 17. P. 6603-6614.

Huff T., 2017. Big Benefits of Using Influencer Marketing in Your Social Strategy. Social Media Today. URL: https://www.socialmediatoday. com/social-networks/6-big-benefits-usinginfluencermarketing-your-social-strategy (date of access: 17.12.2019).

Oleynik O. G., Stepanova E. V., 2019. Formation of Approaches Used to Measure Poverty and Inequality in Russia // Large Projects in Light of Development Strategy 2030-Reality and Ambition : Proceeding of $27^{\text {th }}$ International Conference. № 27. P. 812-820.

Richards G., DuifL., 2018. Small Cities with Big Dreams: Creative Placemaking and Branding Strategies. N. Y. :Routledge. 268 p. DOI: 10.4324/9781351201193.

What Are the Top Influencer Marketing Trends in 2020 ? // Mediakix Team. URL: https://mediakix.com/ influencer-marketing-resources/influencermarketing-trends (date of access: 17.12.2019).

\section{ИСТОЧНИКИ И СЛОВАРИ}

Всё про Арбузы. URL: http://pro-arbuz.ru/arbuznoe/ arbuznyj-festival-v-kamyshine (дата обращения: 17.12.2019).

Камышинский арбузный фестиваль : [офиц. страница в соц. сети «Instagram»]. URL: https:// www.instagram.com/arbuznyfestival/?hl=en (дата обращения: 17.12.2019).

Камышинский арбузный фестиваль : [офиц. страница в соц. сети «VK»]. URL: https://vk.com/ arbuzfest_kam (дата обращения: 17.12.2019).

Отзовик. URL: https://otzovik.com/reviews/arbuzniy_ festival_russia_kamishin (дата обращения: 17.12.2019).

Самараинтур. URL: https://www.samaraintour.ru/ 13688 (дата обращения: 17.12.2019).
Сделано у нас. URL: https://sdelanounas.ru (дата обращения: 17.12.2019).

Уголок России. Камышин и Нижнее Поволжье. URL: http://kamyshinstar.ru (дата обращения: 17.12.2019).

Arbuzfest. URL: https://arbuzfest.ru (date of access: 17.12.2019).

Babyblog. URL: https://www.babyblog.ru/community/ post/travel/3050601 (date of access: 17.12.2019).

Bruges Tourisme. URL: https://www.brugestourisme. com (date of access: 17.12.2019).

Dostoprimechatelnosti-M. URL: https:// dos toprim echatelnosti-m.ru/ dostoprimechatelnosti-kamyshina-spisok-fotoi-opisanie (date of access: 17.12.2019).

MyJulia.Ru. URL: http://www.myjulia.ru/post/431794 (date of access: 17.12.2019).

On the Luce Travel Blog. URL: https://www. ontheluce.com (date of access: 17.12.2019).

Russia Open: национальный туризм. URL: http:// www.russia-open.com (дата обращения: 17.12.2019).

The Blonde Abroad. URL: https://theblondeabroad. com/how-to-spend-24-hours-bruges-belgium (date of access: 17.12.2019).

Travel? Yes Please!. URL: www.travelyesplease.com (date of access: 17.12.2019).

Visit Bruges. URL: https://visit-bruges.be (date of access: 17.12.2019).

Visiter Bruges.com. URL: http://www.visiterbruges.com (date of access: 17.12.2019).

Volgabest // LiveJournal. URL: https://volgabest. livejournal.com/tag/камышин (date of access: 17.12.2019).

Voyages Michelin. URL: https://voyages.michelin.fr (date of access: 17.12.2019).

\section{REFERENCES}

Buletova N.E., Stepanova E.V., 2019. Sravnitelnyy analiz evolyutsii egipetskoy i rossiyskoy ekonomicheskikh sistem [A Comparative Analysis of Evolution of Egyptian and Russian Economic Systems]. Politicheskoe prostranstvo $i$ sotsialnoe vremya: Pravda $i$ lozh v politike $i$ iskusstve: sb. nauch. tr. XXXVI Mezhdunar. Kharak. foruma [Political Space and Social Time: True and False in Politics and Art. Collection of Scientific Papers of the $36^{\text {th }}$ International Kharaks Forum]. Simferopol, Arial Publ., pp. 41-46.

Vizgalov D.V., 2011. Brending goroda [City Branding]. Moscow, Institut ekonomiki goroda. $160 \mathrm{p}$.

Gureeva A.A., 2018. Marketingovaya funktsiya tekstov territorialnogo brendinga [Marketing Function of Place Branding Texts]. Homo Loquens: 
(Voprosy lingvistiki i translyatologii): sb. st. [Homo Loquens (Issues of Linguistics and Translatology). Collected Articles]. Volgograd, Izd-vo VolGU, iss. 11, pp. 34-40.

Dolzhenko D.P., 2019. Opyt razrabotki klassifikatsii sovremennogo rossiyskogo turizma [Experience in Developing a Classification of Modern Russian Tourism]. URL: http://www. intacadem.ru/statji/dolzhenko-g.p.-opytrazrabotki-klassifikatsii-sovremennogorossiyskogoturizma.html (accessed 7 November 2019).

Korolkova S.A., Naumova A.P., 2018. Brending malykh gorodov: lingvisticheskie i pragmaticheskie aspekty [Branding of Small Cities: Linguistic and Pragmatic Aspects]. Kommunikativnye, nominativnye $i$ translatologicheskie aspekty territorialnogo brendinga [Communicative, Nominative and Translatological Aspects of Territorial Branding]. Volgograd, Izd-vo VolGU, pp. 65-81.

Mityagina V.A., 2018. Diskurs marketinga territoriy v kommunikativnom prostranstve WEB $2.0 \mathrm{i}$ WEB 3.0 [The Discourse of Place Marketing in WEB 2.0 and WEB 3.0 Communication Space]. Homo Loquens: (Voprosy lingvistiki $i$ translyatologii): sb. st. [Homo Loquens (Issues of Linguistics and Translatology). Collected Articles]. Volgograd, Izd-vo VolGU, iss. 11, pp. 3-17.

Popova O.I., 2016. Perevod realiy tekstov turisticheskogo diskursa [Translation of the Realities of Tourist Discourse Texts]. Akademicheskaya nauka problemy i dostizheniya: materialy X Mezhdunar. nauch.-prakt. konf. [Academic Science-Problems and Achievements. Proceedings of the $10^{\text {th }}$ International Scientific and Practical Conference]. North Charleston, vol. 2, pp. 151-156.

Popova O.I., 2018. Stilisticheskie sredstva tekstov turisticheskogo brendinga goroda [Stylistic Means of Texts of Tourist Branding of the City]. Kommunikativnye, nominativnye $i$ translatologicheskie aspekty territorialnogo brendinga [Communicative, Nominative and Translatological Aspects of Territorial Branding]. Volgograd, Izd-vo VolGU, pp. 82-96.

Shafranskaya I.N., 2012. Strategii brendinga $v$ territorialnom marketing [Branding Strategies in Territorial Marketing]. URL: https://www. hse.ru/data/2012/09/28/1244118907/Shafranskaya Strategii.pdf(accessed 17 December 2019).

Anholt S., 2009. Places: Identity, Image and Reputation. Palgrave Macmillan. 168 p.

Braun E. City Marketing: Towards an Integrated Approach. URL: https://repub.eur.nl/pub/13694 (accessed 17 December 2019).

Buletova N.E., Zlochevsky I.A., Stepanova E.V., 2017. Structural Analysis and Criteria for Assessment of State Economic Policy. International Journal of Applied Engineering Research, vol. 12, no. 17, pp. 6603-6614.

Huff T., 2017. Big Benefits of Using Influencer Marketing in Your Social Strategy. Social Media Today. URL: https://www.socialmediatoday.com/ social-networks/6-big-benefits-usinginfluencermarketing-your-social-strategy (accessed 17 December 2019).

Oleynik O.G., Stepanova E.V., 2019. Formation of Approaches Used to Measure Poverty and Inequality in Russia. Large Projects in Light of Development Strategy 2030-Reality and Ambition. Proceeding of $27^{\text {th }}$ International Conference, no. 27, pp. 812-820.

Richards G., Duif L., 2018. Small Cities with Big Dreams: Creative Placemaking and Branding Strategies. New York, Routledge. 268 p. DOI: 10.4324/9781351201193.

What Are the Top Influencer Marketing Trends in 2020? Mediakix Team. URL: https:// mediakix.com/influencer-marketing-resources/ influencer-marketing-trends/ (accessed 17 December 2019).

\section{SOURCES AND DICTIONARIES}

Vse pro Arbuzy [Everything About Watermelons]. URL: http://pro-arbuz.ru/arbuznoe/arbuznyjfestival-v-kamyshine/ (accessed 17 December 2019).

Kamyshinskiy arbuznyy festival: [ofits. stranitsa v sots. seti «Instagram»] [Kamyshin Watermelon Festival. Official Webpage in Instagram]. URL: https:/www.instagram.com/arbuznyfestival/ ?hl=en (accessed 17 December 2019).

Kamyshinskiy arbuznyy festival: [ofits. stranitsa $v$ sots. seti «VK»] [Kamyshin Watermelon Festival. Official Webpage in VK]. URL: https:// vk.com/arbuzfest_kam (accessed 17 December 2019).

Otzovik. URL: https://otzovik.com/reviews/arbuzniy_ festival_russia_kamishin/ (accessed 17 December 2019).

Samaraintour. URL: https://www.samaraintour.ru/ 13688 (accessed 17 December 2019).

Sdelano u nas [Made at Our Place]. URL: https:// sdelanounas.ru/ (accessed 17 December 2019).

Ugolok Rossii. Kamyshin i Nizhnee Povolzhye [An Area in Russia. Kamyshin and the Lower Volga Region]. URL: http://kamyshinstar.ru (accessed 17 December 2019).

Arbuzfest. URL: https://arbuzfest.ru (accessed 17 December 2019).

Babyblog. URL: https://www.babyblog.ru/community/ post/travel/3050601 (accessed 17 December 2019). 
Bruges Tourisme. URL: https://www.brugestourisme. com (accessed 17 December 2019).

Dostoprimechatelnosti-M. URL: https:// d os topri m e chat e $1 \mathrm{nos}$ t i - m . r u/ dostoprimechatelnosti-kamyshina-spisokfoto-i-opisanie (accessed 17 December 2019).

Myjulia.ru. URL: http://www.myjulia.ru/post/431794/ (accessed 17 December 2019).

On the Luce Travel Blog. URL: https://www. ontheluce.com/ (accessed 17 December 2019).

Russia Open: natsionalnyy turizm [Russia Open. National Tourism]. URL: http://www.russiaopen.com/ (accessed 17 December 2019).
The Blonde Abroad. URL: https://theblondeabroad. com/how-to-spend-24-hours-bruges-belgium/ (accessed 17 December 2019).

Travel? Yes Please! URL: www.travelyesplease.com (accessed 17 December 2019).

Visit Bruges. URL: https://visit-bruges.be/ (accessed 17 December 2019).

Visiter Bruges.com. URL: http://www.visiterbruges. com (accessed 17 December 2019).

Volgabest. LiveJournal. URL: https://volgabest. livejournal.com/tag/камышин (accessed 17 December 2019).

Voyages Michelin. URL: https://voyages.michelin.fr (accessed 17 December 2019).

\section{Information About the Authors}

Olga I. Popova, Candidate of Sciences (Philology), Associate Professor, Department of Translation Theory and Practice, Volgograd State University, Prosp. Universitetsky, 100, 400062 Volgograd, Russia, tipp@volsu.ru,olgapopova@volsu.ru,https://orcid.org/0000-0001-9787-0317

Svetlana A. Korolkova, Candidate of Sciences (Pedagogy), Associate Professor, Department of Translation Theory and Practice, Volgograd State University, Prosp. Universitetsky, 100, 400062 Volgograd, Russia, tipp@volsu.ru, korolkova@volsu.ru, https://orcid.org/0000-0003-2083-4101

Ekaterina V. Stepanova, Candidate of Sciences (Philology), Associate Professor, Department of Linguistics and Intercultural Communication, Volgograd Institute of Management, Branch of Russian Presidential Academy of National Economy and Public Administration, Gagarina St., 8, 400066 Volgograd, Russia,viu@vlgr.ranepa.ru, stepanova.volg@mail.ru, https://orcid.org/0000-0003-4860-0956

\section{Информация об авторах}

Ольга Ильинична Попова, кандидат филологических наук, доцент кафедры теории и практики перевода, Волгоградский государственный университет, просп. Университетский, 100, 400062 г. Волгоград, Россия, tipp@volsu.ru, olgapopova@volsu.ru, https://orcid.org/0000-0001-9787-0317

Светлана Азадовна Королькова, кандидат педагогических наук, доцент кафедры теории и практики перевода, Волгоградский государственный университет, просп. Университетский, 100, 400062 г. Волгоград, Россия, tipp@volsu.ru, korolkova@volsu.ru, https://orcid.org/0000-0003-2083-4101

Екатерина Владимировна Степанова, кандидат филологический наук, доцент кафедры лингвистики и межкультурной коммуникации, Волгоградский институт управления - филиал Российской Академии народного хозяйства и государственной службы при Президенте РФ, ул. Гагарина, 8, 400066 г. Волгоград, Россия, viu@vlgr.ranepa.ru, stepanova.volg@mail.ru, https://orcid.org/0000-0003-4860-0956 